\title{
Positive somatostatin receptor scintigraphy correlates with the presence of somatostatin receptor subtype 2
}

\author{
M John, W Meyerhof, D Richter, B Waser, J-C Schaer, H Scherübl, J Boese-Landgraf, \\ P Neuhaus, C Ziske, K Mölling, E-O Riecken, J C Reubi, B Wiedenmann
}

\begin{abstract}
Somatostatin receptor scintigraphy (SRS) is positive in approximately $75 \%$ of all patients with neuroendocrine gastroenteropancreatic tumours. This study aimed to identify specific somatostatin receptor (sstr) subtypes, which are responsible for the in vivo binding of the widely used somatostatin analogue, octreotide in human neuroendocrine gastroenteropancreatic tumours. Twelve patients underwent SRS with radiolabelled octreotide. After surgical resection, tumour tissues were analysed in vitro for somatostatin and octreotide binding sites by autoradiography. In addition, for the first time, sstr subtype mRNA expression was examined by semiquantitative reverse transcription polymerase chain reaction (RT-PCR). Tumour tissues from all SRS positive patients were positive by autoradiography. Semiquantitative RTPCR revealed most prominently sstr2 expression in scintigraphically positive tumours. Two SRS negative tumours contained in vitro octreotide binding sites as well as high levels of sstr1 and sstr2 mRNAs. Positive SRS is mainly due to sstr2. sstr1, 3, 4, and probably 5 are less important for in vivo octreotide binding. False negative scintigraphic results seem to be influenced by factors independent of the expression of specific sstr.

(Gut 1996; 38: 33-39)
\end{abstract}

Keywords: somatostatin receptor scintigraphy, somatostatin receptor subtype 2 , octreotide, neuroendocrine tumour, gastroenteropancreatic system, RT-PCR

Neuroendocrine tumour cells of the gastroenteropancreatic system contain high affinity binding sites for somatostatin (SST) and its analogues $\left({ }^{1-3}\right.$, for review see $\left.{ }^{4}\right)$. In 1989, Krenning et $a l^{5} 6$ applied radiolabelled octreotide intravenously to patients with these tumours and showed that they could be localised by somatostatin receptor scintigraphy (SRS). Although most of these tumours were positive by SRS, approximately $25 \%$ were not detected by this technique using octreotide as ligand $\left({ }^{7} 8\right.$, for review see $\left.{ }^{9}\right)$. Interestingly, some of the scintigraphically negative tumours exhibited binding sites for SST but not for octreotide in vitro. ${ }^{1011}$ Additional findings, based on autoradiographic and biochemical binding studies using SST-14, SST-28, and octreotide as ligands, suggested that different somatostatin receptor (sstr) subtypes exist in neuroendocrine tumour cells (for review see ${ }^{4}$ ).

Five distinct human sstr subtypes have recently been identified and characterised by molecular cloning and functional expression studies. ${ }^{12-20}$ For sstr subtype 2 , splice variants sstr2A and sstr2B have been identified. ${ }^{14}$ Thus six sstr subtypes exist up to now. All have been shown to be coupled to G-protein and to possess seven putative membrane spanning domains. ${ }^{21} 22$ sstr subtypes differ in their affinities for specific ligands such as SST-14, SST28 , and the stable somatostatin analogues octreotide and lanreotide $\left({ }^{23}\right.$, for review see $\left.{ }^{24}\right)$. Expression studies of single sstr subtypes in non-neuroendocrine cells found that octreotide bound with high affinity to sstr subtypes 2 and with lower affinity to 3 and 5.1724 Thus, expression of selected sstr subtypes in different tumour types may account for the positive or negative results obtained by SRS.

Recently, Kubota et $a l^{25}$ studied seven neuroendocrine gastroenteropancreatic tumours (pancreas, $n=6$; intestine, $n=1$ ) using the reverse transcription polymerase chain reaction (RT-PCR) and suggested that only sstr 2 was functionally relevant. Interestingly, no expression of sstr 5 was observed in the tumour tissues studied. Furthermore, no quantitation of sstrmRNAs was done and nor was the expression of sstrs studied at the protein level. In addition, the data obtained were not correlated to in vivo binding conditions - that is, SRS.

We have studied a group of patients with neuroendocrine gastroenteropancreatic tumours, who were all subjected to SRS. To evaluate the number of false positive and false negative results obtained using SRS, tumour specimens obtained by surgery from all patients were analysed by means of SST-28 and octreotide autoradiography. In addition, and for the first time, we used a quantitative RT-PCR method to evaluate the expression levels of sstr mRNAs in neuroendocrine tumour tissues.

\section{Patients and methods}

TUMOUR TISSUES

Tumour tissue was obtained from 12 patients with neuroendocrine gastroenteropancreatic tumours by surgery at the Universitätsklinikum Benjamin Franklin (UKBF) and Rudolf Virchow (UKRV), Berlin, Germany. Informed consent was obtained from all patients and the 
study was performed in accordance with the standards set by the ethical committee of the UKBF. Tissue samples were quick frozen in liquid nitrogen and stored at $-80^{\circ} \mathrm{C}$. Tumour histology was verified by both conventional and immunohistological methods before either RNA preparation or SST receptor autoradiography. One atypical carcinoid was studied and showed a positive immunostaining for neuron specific enolase, synaptophysin, but not for chromogranin A, calcitonin, carcinoembryonic antigen (CEA), or serotonin. Focal positive immunoreactivity was also obtained for cytokeratin and vimentin. $\mathrm{Ki} 67$ expression varied from $3-4 \%$ of all tumour cells. By conventional histology, tumour cells were polygonally arranged. By electron microscopy, numerous organelles as well as a few neuroendocrine granules (150 $\mathrm{nm}$ in diameter) were found.

\section{PATIENTS}

Patient characteristics and SRS results are summarised in the Table. SRS was performed as previously described. ${ }^{7826}$ To avoid jeopardy to patients with carcinoid syndrome, SST treatment was continued during SRS or surgery, or both. ${ }^{27}$

\section{RNA PREPARATION}

Total RNA from tumour tissue samples was purified using a modified protocol based on the method of Chomczynski and Sacchi. ${ }^{28}$ Briefly, approximately 10 to $20 \mathrm{mg}$ of tumour tissue were homogenised by sonication in guanidine thiocyanate buffer. The solution was acidified with sodium acetate and extracted once with phenol/chloroform/ isoamyl alcohol, followed by two extractions with chloroform. An equal volume of isopropanol was added to the aqueous phase and the sample was incubated overnight at $-20^{\circ} \mathrm{C}$. Pelleted RNA was washed twice with $75 \%$ ethanol, stored in $75 \%$ ethanol at $-80^{\circ} \mathrm{C}$, and redissolved in RNase-free water before use in reverse transcription.

SEMIQUANTITATIVE PCR

Estimates of the relative levels of mRNAs that

Characteristics of patients with gastroenteropancreatic neuroendocrine tumours

\begin{tabular}{|c|c|c|c|c|c|}
\hline Patient & Age (y) & $\operatorname{Sex}$ & Primary tumour/resected tissu & & SRS Treatment \\
\hline \multirow{12}{*}{$\begin{array}{l}\text { Atypical carcinoid } \\
\text { NE ileal tumour } 1 \\
\text { NE ileal tumour 2 a } \\
\text { NE ileal tumour 2 b } \\
\text { Insulinoma 1 } \\
\text { Gastrinoma } 1 \\
\text { Gastrinoma } 2 \\
\text { Gastrinoma 3 } \\
\text { NE ileal tumour } 3 \\
\text { NE ileal tumour } 4 \\
\text { NE ileal tumour } 5 \\
\text { PNET } 1^{\star} \\
\text { PNET } 2^{\star \star}\end{array}$} & 33 & $\mathrm{~F}$ & Unknown/liver mt & - ve & $\mathbf{s}$ \\
\hline & 60 & $\mathbf{F}$ & Small intestine/ovary $\mathrm{mt}$ & - ve & s, SMS, IFN \\
\hline & 53 & $\mathbf{F}$ & Small intestine/ovary mt & $\begin{array}{l}- \text { ve } \\
\text { tye }\end{array}$ & s, SMS \\
\hline & 66 & $\mathbf{F}$ & Pancreas/p & - ve & s \\
\hline & 39 & $\mathbf{M}$ & Pancreas/p & +ve & s, OMP \\
\hline & 42 & $\mathrm{~F}$ & Liver/p & +ve & s, OMP \\
\hline & 12 & $\mathbf{F}$ & Duodenum/liver $\mathrm{mt}$ & tve & s, SMS, OMP, IFN \\
\hline & 68 & $\mathbf{F}$ & Small intestine/p & + ve & s, SMS \\
\hline & 67 & $\mathbf{M}$ & Small intestine/p & +ve & s, SMS \\
\hline & 59 & $\mathbf{F}$ & Small intestine/liver $\mathrm{mt}$ & +ve & s, SMS \\
\hline & 45 & $\mathbf{M}$ & Pancreas/p & +ve & s, SMS, IFN, ch \\
\hline & 54 & $\mathbf{M}$ & Pancreas/liver mt & + ve & s, SMS \\
\hline
\end{tabular}

All patients were subjected to somatostatin receptor scintigraphy (SRS).

+ve=SRS positive; $-\mathrm{ve}=$ SRS negative

Tumours were functional unless otherwise indicated:

${ }^{\star}$ Non-functional; + serotonin producing.

$\mathrm{NE}=$ neuroendocrine; $\mathrm{PNET}=$ pancreatic neuroendocrine tumour; $\mathrm{F}=$ female; $\mathrm{M}=$ male;

$\mathrm{p}=$ primary tumour; $\mathrm{mt}=$ =metastasis; $\mathrm{s}=$ surgery; $\mathrm{SMS}=$ somatostatin; IFN=interferon;

$\mathrm{OMP}=$ omeprazole; $\mathrm{ch}=$ chemoembolization. encode human sstr subtypes 1-5 has been achieved by PCR amplification of their corresponding cDNAs, using $\beta$-actin mRNA as a control as recently described. ${ }^{29}$ Briefly, $1 \mu \mathrm{g}$ of total cellular RNA that had been prepared from the different tumour tissues and exhaustively digested with DNase I was used for oligo(dT)-primed reverse transcription. cDNAs were amplified with $2.5 \mathrm{U}$ Taq DNA polymerase (Promega, Madison, USA) in 100 $\mu l$ reaction assays using the following oligonucleotide primers:

- sstrl - GCTGAGCAGGACGCCACG and CAACCTGAGAACCTGGAGTCC, corresponding to nucleotide positions 903-923 and 1119-1140 of the published cDNA sequence $^{12}$;

- sstr2 - CCCCAGCCCTTAAAGGCATGT and GGACCCTCCTCAATGGAGACC, 874-895 and 1087-1107 ${ }^{12}$;

- sstr3 - GTCAACGTGGTGTGCCCACTG and GGGCCCCCGGAGAAGACTGAG, 932-952 and $1124^{\circ}-1144^{13}$;

- sstr4 - GCCTTGATGCCACCGTCAACC and GGTGCATGTGCCCCCCACTAA, 956-976 and 1169-1189'19;

- sstr5 - ATCTGTCAACCTGGCCGTGGCG and CGTCCAGACAGGATCCGGCAG, 855-875 and 1056-1076 ${ }^{17}$;

- $\beta$-actin - GGGCATGGGTCAGAAGGATT and ATGAGGTAGTCAGTCAGGTC, 173-192 and 591-610.30

All reaction mixtures were amplified by 40 cycles at $94^{\circ} \mathrm{C}$ for two minutes, at $63^{\circ} \mathrm{C}$ (sstr1 and 4 ), at $61^{\circ} \mathrm{C}$ (sstr2 and 3), at $65^{\circ} \mathrm{C}$ (sstr5), or at $60^{\circ} \mathrm{C}\left(\beta\right.$-actin) for 80 second and at $72^{\circ} \mathrm{C}$ for two minutes. Aliquots $(15 \mu \mathrm{l})$ of each amplification reaction were removed after 15 , $20,25,30,35, \mathrm{~m}$ and 40 cycles, and run on $1.5 \%$ agarose gels. The sizes of the cDNA fragments were found to be $230 \mathrm{bp}$ (sstr1, 2, 4), $210 \mathrm{bp}$ (sstr3), and $220 \mathrm{bp}$ (sstr5) and corresponded to the predicted fragment lengths of $237,233,212,233,221$ nucleotides for sstr1-5, respectively. After blotting on Hybond $\mathrm{N}$ membranes (Amersham, Braunschweig, Germany), filters were hybridised in $5 \times$ SSC, $10 \times$ Denhardt's solution, $1 \mathrm{mM}$ EDTA, 100 $\mathrm{mg} / \mathrm{ml}$ herring sperm DNA, $0.5 \%$ (w/v) sodium dodecylsulphate at $50^{\circ} \mathrm{C}$ with the appropriate ${ }^{32} \mathrm{P}$-labelled sstr or $\beta$-actin probe: - sstr1 - GCTGGATGGACAACGCCGCGG, 1036-1056

- sstr2 - GGCACAGATGATGGGGAGCGG, 1014-1034 12 ;

- sstr3 - TCCCGCCGTGTGCGCAGCCAG, 1091-1111 13 ;

- sstr4 - CCTGCGCTGCTGCCTCCTGGA, 1077-1097 ${ }^{19}$;

- sstr5 - CGCAAGGGCTCTGGTGCCA$A G, 1014^{\prime}-1034^{17}$

- $\beta$-actin - CCACACCTTCTACAATGAGC, $302^{\prime}-321^{30}$;

$1 \mathrm{pmol} / \mathrm{ml}$ with specific activities between $5.2 \times 105$ and $3.8 \times 106 \mathrm{cpm} / \mathrm{pmol}$. Filters were finally washed in $6 \times \mathrm{SSC}$ at either $65^{\circ} \mathrm{C}$ (sstr1, $2,4$, and 5$), 69^{\circ} \mathrm{C}$ (sstr 3 ), or $55^{\circ} \mathrm{C}$ ( $\beta$-actin).

Quantification of the hybridisation signals were carried out using a Bio-Imaging-Analyzer (Fujix BAS 2000, Fuji Photo Film Co, Japan). A 
semilogarithmic plot of pixel values versus cycle number showed that amplification was exponential between cycles 15 and 30 and then reached a plateau. The curves obtained with the $\beta$-actin mRNA and the individual sstr mRNAs displayed similar shapes but were shifted along the $x$ axis. This indicates a similar efficiency in the amplification reaction and that the initial amount of specific cDNA present is crucial to the extent of exponential amplification (see also ${ }^{31}$ for a discussion of quantification). Pixel intensities obtained with sstr specific probes during exponential amplification were expressed relative to those obtained with the $\beta$-actin probe. No cross hybridisation to the other sstr cDNAs was observed with any of the probes (data not shown). All amplifications were carried out at least three times with similar results.

\section{SST AUTORADIOGRAPHY}

Cryostat tissue sections $(20 \mu \mathrm{m})$ were processed for SST receptor autoradiography as previously described in detail. ${ }^{1-3}$ The radioligands used were the SST analogue ${ }^{125} \mathrm{I}$ $\left[\mathrm{Tyr}^{3}\right]$-octreotide and ${ }^{125} \mathrm{I}-\left[\mathrm{Leu}^{8}, \mathrm{D}-\mathrm{Trp}^{22}\right.$, $\mathrm{Tyr}^{25}$ ]-SST-28. Both ligands were iodinated, purified by high pressure liquid chromatography column and characterised in standard binding assays as described previously. ${ }^{13}$ For autoradiography, tissue sections were mounted on precleaned microscope slides and stored at $-20^{\circ} \mathrm{C}$ for at least three days to improve adhesion of tissue to the slide. Sections were then incubated for two hours at ambient temperature in the presence of the iodinated ligand $(0.15-0.30 \times 106 \mathrm{dpm} / \mathrm{ml}$, approximately 80-160 pM). The incubation solution was $170 \mathrm{mM}$ Tris- $\mathrm{HCl}$ buffer ( $\mathrm{pH} \mathrm{7 \cdot 4)}$ containing $1 \%$ bovine serum albumin (BSA), bac-

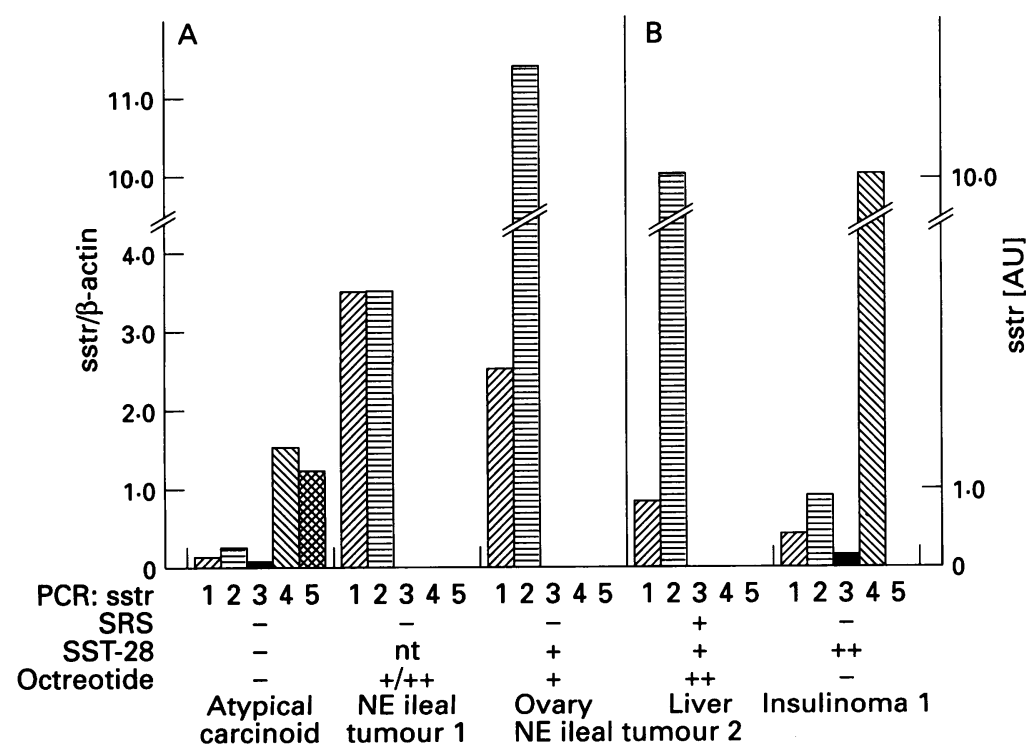

Figure 1: Detection of specific somatostatin receptor (sstr) subtype mRNAs in somatostatin receptor scintigraphy (SRS) negative neuroendocrine gastroenteropancreatic tumour tissues. sstr, relative amounts of somatostatin receptor subtype 1 to 5 mRNAs. sstr subtype mRNAs were analysed by RT-PCR using subtype specific primer pairs, in $(A)$ quantitation was performed in relation to $\beta$-actin $m R N A$ determined as internal control. In panel $(B)$, $\beta$-actin $c D N A$ fragments could not be amplified due to low levels of corresponding $m R N A$, sstr expression was evaluated at a qualitative level only. SRS=somatostatin receptor autoradiography on cryostat sections of tumour tissue samples using SST-28 or octreotide as ligands; somatostatin receptors: -, absence of receptors; +, low to moderate density; ++ , high density; nt, not tested $A U=$ arbitrary units. itracin $(40 \mu \mathrm{g} / \mathrm{ml})$, and $\mathrm{MgCl}_{2}(5 \mathrm{mM})$ to inhibit endogenous proteases. Non-specific binding was determined by adding $1 \mu \mathrm{M}$ solution of unlabelled $\left[\mathrm{Tyr}^{3}\right]$-octreotide or SST-28. Incubated sections were washed twice for five minutes in cold incubation buffer containing $0 \cdot 25 \%$ BSA, then in buffer alone, and dried quickly. Finally, the sections were apposed to ${ }^{3} \mathrm{H}$-Hyperfilms (Amersham, UK) and exposed for one week in $x$ ray cassettes.

\section{Results}

\section{CLINICAL COURSE AND REDUCTION OF} SECRETION IN PATIENTS TREATED WITH SST ANALOGUES

Eight of 12 patients with neuroendocrine tumours had been treated with octreotide $(3 \times 100-500 \mu \mathrm{g} / \mathrm{d}$ subcutaneously, $\mathrm{n}=7$ ) or lanreotide ( $30 \mathrm{mg}$ intramuscularly every 14 days, $n=4$ or $3 \times 5 \mathrm{mg} / \mathrm{d}, \mathrm{n}=3$ ). Two of the eight patients had been treated with a combination of octreotide $(3 \times 250 \mu \mathrm{g} / \mathrm{d})$ subcutaneously and interferon-alpha $(3 \times 5$ mio. IU/wk). All gastrinoma patients were taking omeprazole $\left(20^{`}-40 \mathrm{mg} / \mathrm{d}\right)$. Treatment with SST analogues led to a reduction in flushing and diarrhoea as well as in serum chromogranin A concentrations in all patients with carcinoid syndrome $(n=6)$. Abnormal serum concentrations of serotonin (six of six) or gastrin (one; two not tested) were reduced after SST treatment. No correlation between SRS positivity and the control of tumour growth was observed.

\section{SRS}

SRS showed neuroendocrine tumour lesions in eight of 12 patients (Table). The tumours in these eight patients consisted of gastrinomas $(n=3)$, neuroendocrine tumours of the small intestine $(n=3)$, and neuroendocrine pancreatic tumours $(n=2)$. In four of 12 patients negative SRS results were obtained (Table). These four patients suffered from insulinoma $(n=1)$, atypical carcinoid (liver metastasis and unknown primary tumour, $n=1$ ), and functional neuroendocrine ileal tumours $(n=2)$, one with metastases of the liver and ovary and one with only an ovarian metastasis. Although the liver metastasis was positive by SRS, the metastases to the ovaries, which were 3 or $4 \mathrm{~cm}$ in diameter, were negative in the latter two patients. Tumour tissues obtained from all these patients during surgery were studied for the expression of the various sstr subtypes by SST autoradiography and semiquantitative RT-PCR. Since the diagnostic reliability of SRS is not compromised by continuous treatment with somatostatin analogues, ${ }^{27}$ somatostatin treatment was not stopped before SRS.

\section{AUTORADIOGRAPHY WITH SST-28 AND}

OCTREOTIDE AS SST RECEPTOR LIGANDS

Binding studies of single sstr subtypes transfected and expressed in non-neuroendocrine cells have shown that octreotide binds 


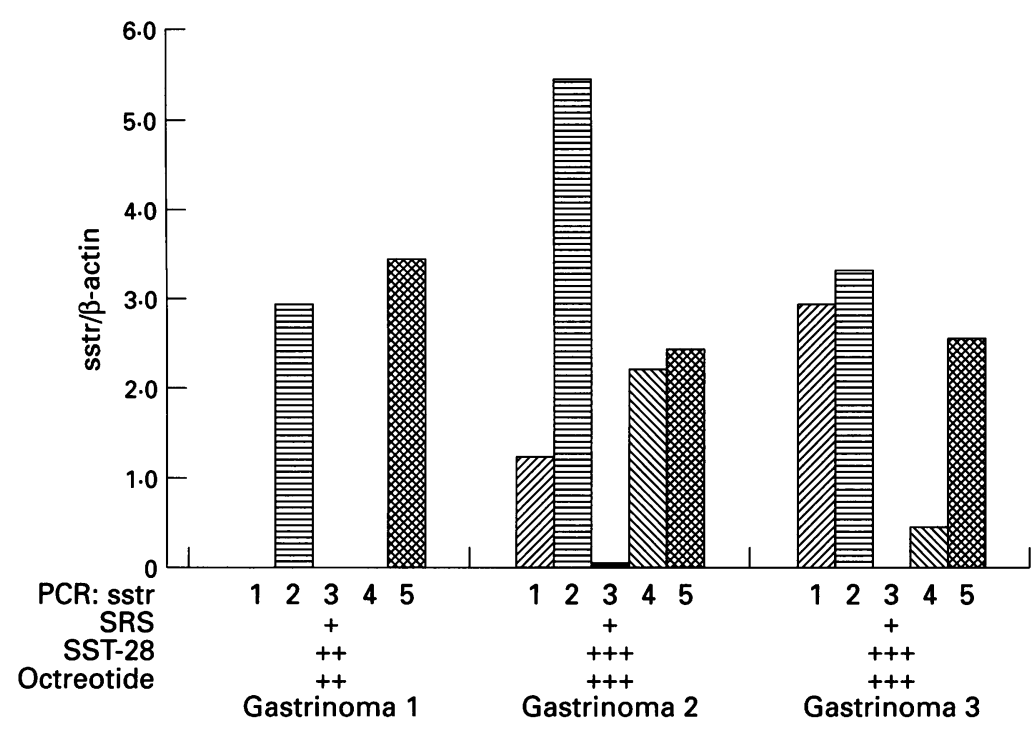

Figure 2: Detection of specific somatostatin receptor (sstr) subtype mRNAs in somatostatin receptor scintigraphy (SRS) positive gastrinoma tissue samples. sstr subtype mRNAs were analysed as described in the legend to Figure 1. For abbreviations see Figure 1.

Somatostatin receptors: ++ , high density; +++ , very high density.

only to sstr 2 with high affinity ${ }^{24}$ and to a lesser extent to sstr5. ${ }^{17}$ Using octreotide as well as the universal ('panligand') SST-28 as radioligand, specific binding sites were found in most tumour tissue samples (Figs 1-4). However, the atypical carcinoid and the insulinoma showed no specific octreotide binding as determined by autoradiography (Figs 1 and $5 \mathrm{C}-\mathrm{F}$ ). This agrees with the negative SRS results in these two patients. In contrast, in two patients metastases of the ovary that had been missed by SRS using octreotide as ligand were positive by octreotide autoradiography (Fig 1). Interestingly, the liver metastasis of one of these patients exhibited octreotide binding sites both by SRS and by autoradiography. This suggests that depending on the metastatic organ additional factors such as tumour vascu-

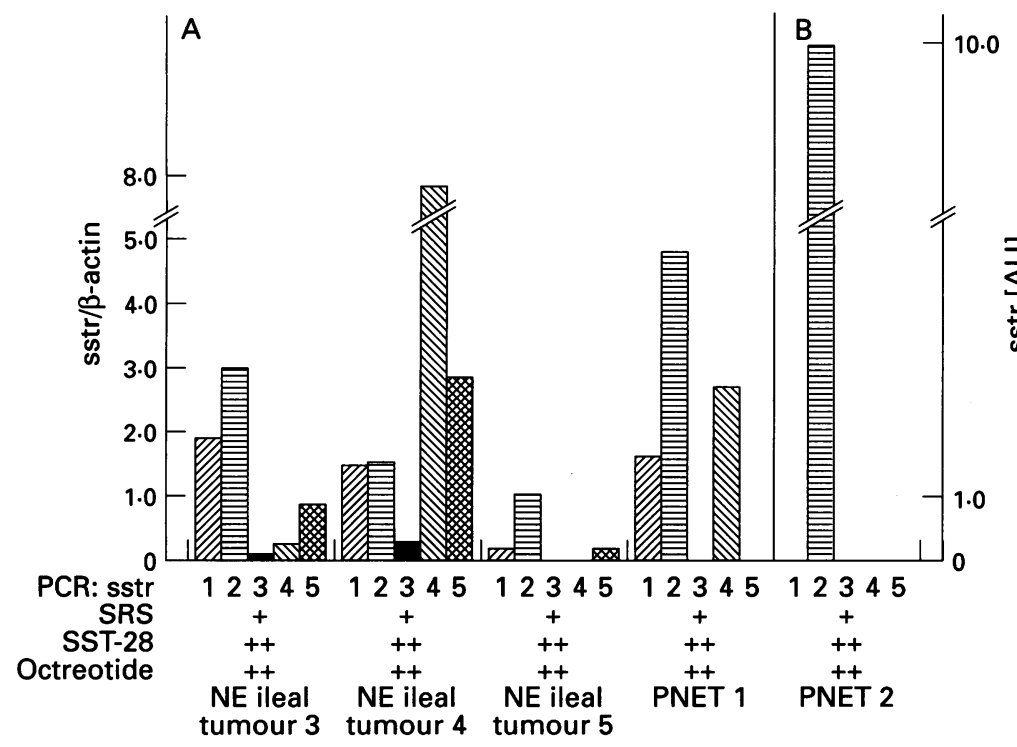

Figure 3: Detection of specific somatostatin receptor (sstr) subtype mRNAs in somatostatin receptor scintigraphy (SRS) positive neuroendocrine gastroenteropancreatic tumour tissue samples. sstr subtype mRNAs were analysed as described in the legend to Figure 1. In panel (A) quantitation was performed in relation to $\beta$-actin $m R N A$ determined as internal control. In panel (B), $\beta$-actin cDNA fragments could not be amplified due to low levels of corresponding $m R N A$, sstr expression was only evaluated at a qualitative level. For abbreviations see Figure 1. larisation, occupation of the ligand binding site, endocytotic rate, etc add to the positive or negative signal in SRS. In addition to SST-28 binding, high levels of octreotide binding were found in all gastrinoma tissues (Fig 2) and in tissues of neuroendocrine ileal and pancreatic tumours (Figs 3, and $4 \mathrm{~A}$ and $\mathrm{B}$ ). This indicates that the observed positive SRS findings are indeed true positive.

SSTR SUBTYPE MRNA

The abundance of sstr subtype mRNAs was quantified in relation to $\beta$-actin mRNA expression. In three tissue samples, determination of $\beta$-actin mRNA was not possible. In these experiments the $\beta$-actin mRNA levels were apparently too low to be detected after 40 cycles of amplification. However, sstr-mRNA species have been amplified (insulinoma, $n=1$; neuroendocrine ileal tumour $\mathrm{n}=12$, liver metastasis, $\mathrm{n}=1$; serotonin producing pancreatic tumour, PNET 2, n=1; Figs 1 and 3). Figure 1 shows the RT-PCR data obtained from tumour tissue samples of all patients negative by SRS. Two patients were negative both by SRS and octreotide autoradiography. In one of these patients (atypical carcinoid), mRNA levels for sstrs were comparably low in comparison to SRS positive tumour tissues such as gastrinomas (see below). In the other patient (insulinoma 1), moderate amounts of sstr1 and sstr 2 mRNAs but high levels of sstr4 mRNA were detected at a qualitative level (see above). This suggests that SRS negative tumours do not synthesise sufficient receptor protein for adequate visualisation. Only sstr subtype 1 and 2 mRNAs were consistently detected at high levels in all SRS negative cases that showed positive octreotide autoradiography. Interestingly, in one patient with a neuroendocrine ileal tumour metastatic to the liver and the ovary, the sstr 1 and 2 transcripts were observed in both metastases (Fig 1). As already pointed out, SRS was only positive in the liver in this patient. The positive autoradiography with octreotide in both metastases (liver and ovary) probably accounts for the sstr2 subtype. ${ }^{32}$

In vivo binding of octreotide to sstr subtype 2 is especially supported by one patient with an serotonin producing pancreatic tumour (PNET 2), in whom octreotide autoradiography was positive and only sstr subtype 2 mRNA was found by RT-PCR (Fig 3).

Gastrinomas, known to be almost always positive by in vitro autoradiography and by SRS, showed consistently high expression of sstr subtypes 2 and 5 mRNAs (Fig 2). This observation, taken together with binding studies of octreotide on cultured cells transfected with various sstr subtypes, ${ }^{24} 25$ suggests that sstr subtypes 2 and perhaps 5 were responsible for positive signals in both autoradiography and SRS.

In summary, analysis of the expression of the mRNAs of all sstr subtypes in tumour tissues $(n=13)$ from all patients $(n=12)$ investigated showed a heterogeneous pattern. sstr2 was most frequently found (13 of 13), followed by sstr 1 

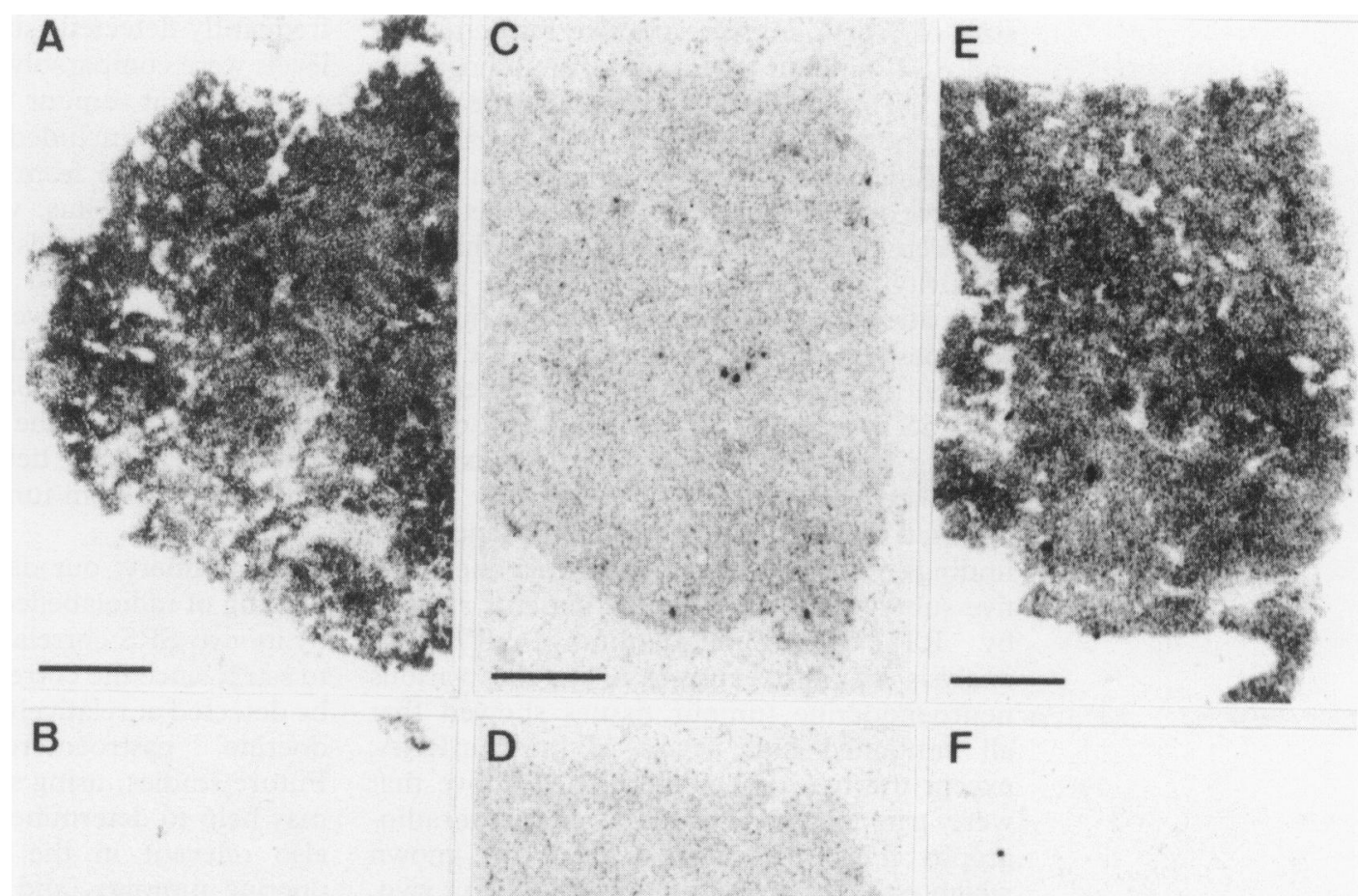

$\mathrm{F}$

Figure 4: In vitro detection of somatostatin receptors by autoradiography. Left panels - neuroendocrine (NE) ileal tumour 4. (A) Autoradiogram showing total binding of ${ }^{125}$ I-[ Tyr $\left.{ }^{3}\right]$-octreotide. (B) Autoradiogram showing non-specific binding. Bar $=1 \mathrm{~mm}$. Right panels - Insulinoma 1. (C) Autoradiogram showing total binding of ${ }^{125}$ I-[Tyr $\left.{ }^{3}\right]$-octreotide.

(D) Autoradiogram showing non-specific binding. (E) Autoradiogram showing total binding of $125 I-\left[L e u^{8}, D-T r p^{22}\right.$, Tyr's]-SST-28. (F) Autoradiogram showing non-specific binding. Bar=1 mm. High density of SST receptors with a high affinity for octreotide was detected in the neuroendocrine (NE) ileal tumour 4. In the insulinoma, however, a high density of SST receptors with a high affinity for SST-28 but not for octreotide was identified.

(11 of 13), sstr5 (seven of 13), and sstr4 (seven of 13). sstr subtype 3 transcripts were detected only at low levels or not at all throughout all tissue samples studied (six of 13) (Figs 1-3).

\section{Discussion}

Binding sites for SST-14, SST-28, and the clinically relevant SST analogue octreotide have been found in a large number of neuroendocrine tumours by in vitro radioligand and autoradiographic techniques. ${ }^{1-4}$ Using SRS, in vivo binding of octreotide to neuroendocrine tumours was initially observed by Krenning et $a l^{56}$ and was later confirmed by others. ${ }^{782633}$ To date, the expression of the known five main sstr subtypes (for nomenclature see ${ }^{24}$ ) has been examined only in a small number of patients with neuroendocrine tumours of the pancreas and intestine by a non-quantitative RT-PCR approach. ${ }^{25}$ In this study, we have assessed the composition of sstr subtypes in human neuroendocrine tumour tissue by semiquantitative RT-PCR, by autoradiography using SST-
28 and octreotide as SST receptor ligands, and in vivo using SRS. This allows us to draw conclusions about false positive and false negative findings obtained by SRS as well as about the sstr subtypes involved in octreotide binding in vivo. SRS was performed in all 12 patients and failed to detect tumour lesions in four patients (Table, Fig 1). Interestingly liver metastases were positive by SRS whereas an ovarian metastasis was negative in the same patient (Table, Fig 1). It is noteworthy that eight out of 12 patients, and particularly all three patients with gastrinomas, were positive by SRS (Table, Figs 2 and 3). To determine whether the intravenously applied, radiolabelled SST analogue octreotide bound to specific receptors in vivo, an in vitro analysis of SST binding sites and sstr subtypes present in the respective tumour tissues was performed. As demonstrated by in vitro autoradiography, two of the four patients who were diagnosed to be negative by SRS were true negative for octreotide binding (Fig 1). However, in two other patients ovarian metastases that had been missed by SRS despite their 
sizes of 3 or $4 \mathrm{~cm}$ were positive for octreotide and SST binding by in vitro autoradiography (Fig 1). This indicates that at least some neuroendocrine tumour lesions are false negative by SRS. Since one of the two patients with SRS negative ovarian metastases had liver metastases that were positive by SRS, we suggest that SRS positivity may depend not only on the expression pattern and expression levels of various sstr subtypes (see below) but also on the blood supply, locally high concentrations of endogenous SST, as well as down regulation of SST binding sites by various factors (for example, corticosteroids).

Based on our autoradiographic and SRS findings, we expected to find at least one of the five subtypes in 10 out of 12 patients studied by RT-PCR. Semiquantitative RT-PCR analysis of sstr expression in the various neuroendocrine tumour tissues showed that all contained high levels of sstr2 mRNA, except the two tissues mentioned above that were true negative by SRS and autoradiography (Figs 1-3). To date, it is not known which sstr subtype(s) binds octreotide in vivo. Transfection studies in cultured non-neuroendocrine cells expressing an individual sstr subtype suggest that human sstr2 may fulfil this role. ${ }^{2425}$ Moreover, in vitro binding of labelled octreotide to human neuroendocrine tumours correlated with the presence of sstr2 subtype mRNA. ${ }^{32}$ Since only sstr 2 mRNA was detected in tumour tissue of one of our patients (Fig 3) and since the tumour had been positive by SRS and autoradiography, we consider this the first direct evidence for high affinity binding sites of octreotide to sstr2 in vivo.

Gastrinomas generally exhibit high uptake of radiolabelled octreotide in vivo and show high incidence of sstr by autoradiography. 49 All of our gastrinoma patients were strongly positive by SRS, and tumour tissues of these patients contained both sstr 2 and sstr 5 transcripts (Fig 2). It is noteworthy that only sstr2 and sstr 5 mRNAs were detected in tumour tissue of one of the three gastrinoma patients (Fig 2). Since the intensity of receptor scintigram in this patient was similar to that of the two other gastrinoma patients expressing additional sstr subtype mRNAs, we suggest that in addition to sstr 2 sstr 5 may also bind octreotide in vivo, since both subtypes possess reported high affinity binding sites for octreotide at least in vitro. ${ }^{24}$ Other sstr subtypes seem to be less important for the positivity of SRS.

Interestingly, in one patient with a primary, ileal neuroendocrine tumour metastatic to the liver and ovary, only sstr 1 and 2 were found in all tissues studied (Fig 1), which supports the suggestion $^{325}$ that the expression patterns of sstr subtypes may be conserved during the metastatic process in a tumour specific fashion. Analysis of the expression of the mRNAs of all sstr subtypes in tumour tissues $(n=13)$ from all patients $(n=12)$ investigated showed a heterogeneous pattern, sstr2 was most frequently found (13 of 13), followed by sstr1 (11 of 13), sstr5 (seven of 13) and sstr4 (seven of 13). Expression of sstr3 transcripts was the least frequently detected (six of 13) and expression levels were comparably low.

Analysis of tumour tissues homogenates by RT-PCR also included non-tumour cells such as those derived from connective tissues and blood vessels. Thus, we cannot exclude that normal tissue and cells contributed to the positive signals obtained by RT-PCR. In vitro autoradiography, however, detected only binding sites on tumour cells, suggesting that nontumour cells express SST protein at low levels only. Thus, despite the extremely high sensitivity of RT-PCR, the detected sstr mRNAs may derive mainly from tumour cells and not from others.

In summary, our data suggest that specific binding of radiolabelled octreotide as detected by in vivo SRS correlates mainly with binding to sstr2, since the corresponding transcript can be detected at relatively high levels in neuroendocrine gastroenteropancreatic tumours. Future studies, using subtype specific ligands, may help to determine whether sstr $1,3,4$ are also relevant in the diagnosis of neuroendocrine tumours, and may lead to improved symptomatic and antiproliferative SST treatment of this disease.

The authors thank I Eichhorn (Berlin) and $\mathrm{H} \mathrm{H}$ Hönk (Hamburg) for expert technical assistance. This study was supported in part by grants from the Deutsche Krebshilfe/Dr $M$ Scheel-Stiftung (W31/91/Wi 1), Verum-Stiftung, and the Deutsche Forschungsgemeinschaft (SFB 366/A5) to BW; Deutsche Forschungsgemeinschaft (Sche $326 / 3-1$ ) to HS; and Deutsche Forschungsgemeinschaft (SFB 232/B4) to WM and DR.

Part of this work was presented at the 10th International Symposium on Gastrointestinal Hormones, Santa Barbara, Symposium on Gastrointestinal Hormones, Santa Barbara,
California, August 27-31, 1994 and was published in abstract California, August 27-31, 1994 and was published in abstract
form (Scherübl H John M, Meyerhof W, Raulf F, Bruns Ch,
Reubi JC, et al. Somatostatin receptor subtypes in neuroendocrine cell lines and tumor tissues of the gastroenteropancreatic system. Dig Dis Sci 1994; 39 (8): 1787).

1 Reubi JC, Haecki WH, Lamberts SWJ. Hormone-producing gastrointestinal tumors contain a high density of somatostatin receptors. $\mathcal{F}$ Clin Endocrinol Metab 1987; 65: 1127-34.

2 Reubi JC, Maurer R, von Werder K, Torhorst J, Klijn JGM, Lamberts SWJ. Somatostatin receptors in human endocrine tumors. Cancer Res 1987; 47: 551-8.

3 Reubi JC, Kvols LK, Waser B, Nagorney DM, Heitz PU, Charboneau JW, Reading CC, Moertel C. Detection of somatostatin receptors in surgical and percutaneous needle biopsy samples of carcinoids and islet cell carcinomas. Cancer Res 1990; 50: 5969-77.

4 Reubi JC, Laissue J, Waser B, Horisberger U, Schaer JC. Expression of somatostatin receptors in normal, inflamed and neoplastic human gastrointestinal tissues. Ann NY Acad Sci 1994; 733: 122-37.

5 Krenning EP, Breeman WAP, Kooij PPM, Lameris JS, Bakker WH, Koper JW, Ausema I, Reubi JC, Lamberts SWJ. Localisation of endocrine-related tumours with radioiodinated analogue of somatostatin. Lancet 1989; 242-4.

6 Lamberts SWJ, Bakker WH, Reubi JC, Krenning EP. Somatostatin-receptor imaging in the localization of endocrine tumors. N Engl F Med 1990; 323: 1246-9.

7 Scherübl H, Bäder M, Fett U, Hamm B, Schmidt-Gayk H, Koppenhagen K, Dop F-J, Riecken E-O, Wiedenmann B. Somatostatin-receptor imaging of neuroendocrine gasSomatostatin-receptor imaging of neuroendocrine gastroenteropar

8 Zimmer T, Ziegler K, Bäder M, Fett U, Hamm B, Riecken $\mathrm{E}-\mathrm{O}$, Wiedenmann $\mathrm{B}$. Localisation of neuroendocrine tumors of the upper gastrointestinal tract. Gut 1994; 35: 471-5.

Krenning EP, Kwekkeboom DJ, Oei HY, de Jong RJB, Dop FJ, Reubi JC, Lamberts SWJ. Somatostatin receptors in gastroenteropancreatic tumors: on overview of European results. Ann NY Acad Sci 1994; 733: 416-24.

10 Lamberts SWJ, Hofland LJ, van Koetzveld PM, Reubi JC Bruining HA, Bakker WH, Krenning EP. Parallel in vivo and in vitro detection of functional somatostatin receptors and in vitro detection of functional somatostatin receptors in human endocrine pancreatic tumors: consequences with regard to diagnosis, localization,
Endocrinol Metab 1990; 71: 566-74.

11 Kvols LK, Brown ML, O'Connor MK, Hung JC, Hayostek RJ, Reubi JC, Lamberts SWJ. Evaluation of a radiolabeled somatostatin analog (I-123 octreotide) in the detection 
and localisation of carcinoids and islet cell tumors. Radiology 1993; 187: 129-33.

12 Yamada Y, Post SR, Wang K, Tager HS, Bell GI, Seino S Cloning and functional characterization of a family of human and mouse somatostatin receptors expressed in human and mouse somatostatin receptors expressed in brain, gastrointestinal tract,

13 Yamada Y, Reisine T, Law SF, Ihara Y, Kubota A, Kagimoto S, et al. Somatostatin receptors, an expanding gene family: cloning and functional characterization of human sstr 3, a protein coupled to adenylyl cyclase. Mol Endocrinol 1992; 6: 2136-42.

14 Patel YC, Greenwood M, Kent G, Panetta R, Srikant CB. Multiple gene transcripts of the somatostatin receptor sstr2: tissue selective distribution and cAMP regu Bstr2: tissue selective distribution and CAMP reg

15 Corness JD, Demchyshyn LL, Seeman P, van Tol HHM, Srikant CB, Kent G, Patel YC, Niznik HB. A human somatostatin-14 like peptides. FEBS Let 1993; 321: 279-84.

$16 \mathrm{Xu} \mathrm{Y}$, Song J, Bruno JF, Berelowitz M. Molecular cloning and sequencing of a human somatostatin receptor, hsstr4. Biochem Biophys Res Commun 1993; 193: 648-52.

17 Yamada Y, Kagimoto S, Kubota A, Koichiro Y, Masuda K, Yoshimichi S, Ihara Y, Li Q, Imura H, Seino S, Seino Y. Cloning, functional expression and pharmacological characterization of a fourth (hsstr4) and fifth (hsstr5) human somatostatin receptor subtype. Biochem Biophys Res Commun 1993; 195: 844-52.

18 Demchyshyn LL, Srikant CB, Sunahara RK, Kent G, Seeman P, van Tol HHM, Panetta R, Patel YC, Niznik Seeman P, van Tol HHM, Panetta R, Patel YC, Niznik $\mathrm{HB}$. Cloning and expression of a human somatostatin-14selective receptor variant (somatostatin receptor 4) 894-901.

19 Rohrer L, Raulf F, Bruns C, Hofstädter F, Büttner R, Schüle R. Cloning and characterization of a fourth human somatostatin receptor. Proc Natl Acad Sci USA 1993; 90: 4196-200.

20 Panetta R, Greenwood MT, Warszynska A, Demchyshyn LL, Day R, Niznik HB, Srikant CB, Patel YC. Molecular cloning, functional characterization, and chromosomal localization of a human somatostatin receptor (somatolocalization of a human somatostatin receptor (somatostatin receptor type 5) with preferential affinity

21 Patel YC, Greenwood MT, Warszynska A, Panetta R, Srikant CB. All five cloned human somatostatin receptors (hsstr1-5) are functionally coupled to adenylyl cyclase. Biochem Biophys Res Commun 1994; 198: 605-12.
22 Bell GI, Reisine T. Molecular biology of somatostatin receptors. TINS 1993; 16: 34-8.

23 Rens-Domiano S, Reisine T. Biochemical and functional properties of somatostatin receptors. $\mathcal{F}$ Neurochemy 1992; 58: 1987-96.

24 Bruns C, Weckbecker G, Raulf F, Kaupmann K, Schoeffter $P$, Hoyer D, Lübbert $H$. Molecular pharmacology of somatostatin receptor subtypes. Ann NY Acad Sci 1994; 733: $138-46$.

25 Kubota A, Yamada Y, Kagimoto S, Shimatsu A, Imamura $M$, Tsuda K, Imura H, Seino S, Seino Y. Identification of somatostatin receptor subtypes and an implication for the efficacy of somatostatin analogue SMS 201-995 in treatment of human endocrine tumors. $\mathcal{f}$ Clin Invest $1994 ; 93$ : 1321-5.

26 Wiedenmann B, Bäder HM, Scherübl H, Fett U, Zimmer $T$, Hamm B, Koppenhagen $K$, Riecken E-O. Gastroenteropancreatic tumor imaging with somatostatin-receptor scintigraphy. Semin Oncol; 1994; 21 (suppl): 29-32

27 Dörr V, Wurm K, Höring K, Gozman G, Räth U, Bihl H. Diagnostic reliability of somatostatin receptor scintigraphy during continuous treatment with different somatostatin analogs. Horm Met Res 1993; 27 (suppl): 36-43.

28 Chomczynski P, Sacchi N. Single-step method of RNA isolation by acid guanidiniumthyocyanate-phenol-chloroform extraction. Analytical Biochemistry 1987; 162: 156.

29 Wulfsen I, Meyerhof W, Fehr S, Richter D. Expression patterns of rat somatostatin receptor genes in pre- and postnatal brain and pituitary. $\mathcal{F}$ Neurochem 1993; 61: 1549-52.

30 Ponte P, Ng SJ, Engel J, Gunning P, Kedes L. Evolutionary conservation in the untranslated regions of actin mRNAs: DNA sequence of a human beta-actin cDNA. Nucleic Acids Res 1984; 12: 1687-6.

31 Chelly J, Kaplan JC, Maire P, Gautron S, Kahn A. Transcription of the dystrophin gene in human muscle and non-muscle tissues. Nature 1988; 333: 858-60.

32 Reubi JC, Schaer JC, Waser B, Mengod. Expression and localization of somatostatin receptor sstr1, sstr2, and sstr 3 mRNAs in primary human tumors using in situ hybridization. Cancer Res 1994; 54: 3455-9.

33 Nocaudie-Calzada $M$, Huglo D, Deveaux M, Carnaille B, Proye C, Marchandise X. Iodine-123-Tyr-3-octreotide uptake in pancreatic endocrine tumors and in carcinoids in relation to hormonal inhibition by octreotide. $\mathcal{F}$ Nucl Med 1994; 35: 57-62. 


\section{LETTERS TO THE EDITOR}

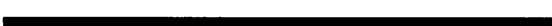

\section{Drug induced pancreatitis}

EDITOR,-I have read with interest the article on drug induced pancreatitis by Lankisch et al (Gut 1995; 37: 565-7). It is unclear to me how the opinion that in $1.4 \%$ of patients disease was drug induced could have been substantiated.

It is difficult to believe that only 22 of 1613 patients were exposed to drugs. What about drugs taken by the remaining 1591 ; is opinion enough to exclude possible causation, plainly not.

To estimate the true impact of drug induced disease the authors would have had to conduct a controlled study. Nevertheless, the authors have concluded that drug induced acute pancreatitis occurs rarely in clinical practice. That opinion has not been substantiated by this study.

M J S LANGMAN Department of Medicine, Queen Elizabeth Medical Centre, Queen Elizabeth Hospital, Edgbaston, Birmingham B12 2TH

\section{Reply}

EDITOR,-We are grateful for the interest Professor M J S Langman took in our paper and regret that it has obviously given rise to some misunderstanding.

The preselection of patients diagnosed for drug induced acute pancreatitis was made by the centres where they had been treated. All charts of patients considered to fall into this group were reviewed by us. We looked only for drugs, however, currently held responsible for inducing acute pancreatitis. It is possible that in the 135 patients with acute pancreatitis of unknown aetiology drugs had been given still unknown to induce acute pancreatitis and thus the incidence of this aetiology might be somewhat higher.

Prospective studies help to answer open questions but logistic realities pose problems. The two questions at issue are: how frequently does the application of a certain drug lead to acute pancreatitis and, how frequent is drug induced acute pancreatitis among all patients with acute pancreatitis?

The first question is impossible to answer. In view of the great number of patients receiving drugs such as frusemide and oestrogen, it would be impossible to follow up all of them for signs and symptoms of acute pancreatitis. Even the second question is difficult to answer. To make quite sure that the suspected drug has really induced the disease, a re-exposure to the drug in question is necessary, something ethically difficult to justify.

The message of our paper was simply that drug induced acute pancreatitis is probably rare and that the disease usually takes a benign course. Such a retrospective evaluation in a substantial number of patients has not been done before.

P G LANKISCH Department of Internal Medicine, Municipal Hospital of Lüneburg, D-21339 Lüneburg, Germany

\section{Biliary stenting in the management of} bile duct stones

EDITOR, - We read with interest the leading article by Dalton and Chapman (Gut 1995; 36: 485-7). Their suggestion that a sphincterotomy may not always be necessary in these patients is absolutely valid. We would go a step further in stating that in such patients, if the size of the stone is $>15-20 \mathrm{~mm}$ at ultrasound examination or ERCP, then stenting should be performed with a 7 French stent without sphincterotomy. This will prevent the complications associated with endoscopic sphincterotomy, which occur in $8-10 \%$ of patients undergoing the procedure. ${ }^{1}$ Furthermore, this would prevent migration of straight stents. As already mentioned in the leading article, there is no evidence to show so far, that 10 French stents are superior to stents of smaller diameter. Although 7 French stents tend to clog earlier than the 10 French ones, ${ }^{2}$ they may easily be exchanged when blockage occurs. Endoscopic sphincterotomy may however be required if multiple stents need to be placed.

Apart from maintaining the flow of bile and preventing stone impaction and cholangitis, stenting has other benefits too. Placement of biliary endoprostheses has been shown to decrease the size of the stones on follow up. ${ }^{34}$ Moreover, in patients with stricture of the common bile duct, where lithotripsy may be difficult or impossible, biliary endoprostheses may resolve such strictures ${ }^{5-7}$ in addition to decreasing the size of the stone.

S P MISRA M DWIVEDI

\section{Department of Gastroenterology,} MLN Medical College, Allahabad - 211 001, India

1 Cotton PB. Endoscopic management of bile duct stones; (apples and oranges). Gut 1984; 25: stones;

2 Status evaluation: biliary stents. Gastrointest Endosc 1992; 38: 750-2.

3 Chan ACW, Ng EKW, Lai CW, et al. Common bile duct stones become smaller after endoscopic biliary stenting. [Abstract]. Gastrointest Endosc 1995; 41: 393.

4 Vallera RA, McGee SG, Shearin M, et al. Biliary stents decrease the size of retained common bile duct stones. [Abstract]. Gastrointest Endosc 1995; 41: 419.

5 Bourke MJ, Elfant AB, Alhalel R, Kotan P, Haber GB. Biliary and pancreatic strictures complicating endoscopic biliary sphincterotomy. [Abstract]. Features and endoscopic otomy. [Abstract]. Features and endoscopic

6 Hmeidan A, Jacob J, Sherman S, Lehman GA Hmeidan A, Jacob J, Sherman S, Lehman GA.
Benign biliary strictures: outcome of endoscopic therapy. [Abstract]. Gastrointest Endosc 1995; 41: 399.

7 Hmeidan A, Jacob J, Sherman S, Lehman GA. Benign biliary strictures: frequency and management at ERCP. [Abstract]. Gastrointest Endosc 1995; 41: 399.

\section{BOOK REVIEW}

Inflammatory Bowel Disease. 4th ed. Edited by J B Kirsner, R G Shorter. (Pp 1033; illustrated; $£ 116)$. Baltimore: Williams and Wilkins, 1995. ISBN 0-683-04627-6.

The fourth edition of 'Kirsner and Shorter' appears exactly 20 years after the first edition and is a tribute to the extraordinary energy of its editors. Compared with the third edition published in 1985, the current volume has expanded by over 200 pages and many new authors have been introduced. It remains an all American book but its perspective of the literature is global and generally well balanced. Inevitably in a book of 41 chapters devoted to two diseases, there is some repetition but this is no bad thing if the volume is used for reference or for browsing. The largest expansion compared with previous editions concerns pathogenesis - 11chapters compared with six in the third edition. This rightly reflects the remarkable explosion of interest in the immunological and inflammatory mechanisms in pathogenesis that has occurred during the past $10-15$ years.

This volume provides us with the most comprehensive account of ulcerative colitis and Crohn's disease currently available. It is obsessively referenced and therefore provides an excellent entry into the original literature. It provides elegant accounts of the experimental, immunological, and pathophysiological mechanisms that may be involved in pathogenesis but also provides detailed accounts of medical and surgical treatment The psychosocial problems of the diseases are amplified by a final chapter written from the perspectives of an affected subject and a multiply affected family.

Clinical gastroenterologists will find this book invaluable, those in training will find a mine of information, and for the IBD specialist it will continue to be a much used book of reference. It well lives up to its aims as described in the preface although I am not as sanguine as the editors that the aetiology of either disease will be understood within the next five years.

D P JEWELL

\section{CORRECTION}

An error occurred in the paper by Dr John and others (Gut 1996; 38: 33-39). The title of the paper should read 'Positive somatostatin receptor scintigraphy correlates with the presence of somatostatin receptor subtype 2 and 5 '. 